\title{
MODEL KESESUAIAN LAHAN UNTUK TANAMAN JAGUNG MENGGUNAKAN METODE ANALISIS SPASIAL DI KECAMATAN LUBUK BASUNG KABUPATEN AGAM
}

\author{
Ade Irma Suryani ${ }^{1)}$, Loli setriani ${ }^{2)}$ \\ 1. Dosen STKIP PGRI Sumatera Barat \\ 2. Dosen STKIP PGRI Sumatera Barat \\ Jln Gunung Pangilun Kota Padang, \\ Email: Adeirmasuryani@stkip-pgri-sumbar.ac.id ${ }^{11}$, lolisetriani@stkip-pgri-sumbar.ac.id ${ }^{2)}$
}

\begin{abstract}
ABSTRAK
Lahan adalah bagian dari bentang alam (landscape) yang mencakup pengertian lingkungan fisik (iklim, topografi, hidrologi, bahkan keadaan vegetasi alami) yang semuanya secara potensial akan berpengaruh terhadap penggunaan lahan. Malingreau (Muryono (2005). Evaluasi lahan merupakan suatu pendekatan atau cara untuk menilai potensi sumberdaya lahan. Hasil evaluasi lahan akan memberikan informasi dan /atau model arahan penggunaan lahan yang diperlukan. Tujuan penelitian ini adalah : Analisis tingkat kesesuaian lahan untuk tanaman jagung di Kecamatan Lubuk Basung Kabupaten Agam Untuk menjawab tujuan tersebut, hal-hal yang dilakukan adalah: 1) Menganalis kondisi kesesuaian lahan pada tanaman jagung di Kecamatan Lubuk Basung Kabupaten Agam. 2) Mengevaluasi tingkat kesesuian lahan pada tanaman jagung di Kecamatan Lubuk Basung Kabupaten Agam 3) Membuat Peta Model Kesesuaian lahan untuk tanaman jagung menggunakan metode analisis Spasial di Kecamatan Lubuk Basung Kabupaten Agam. Penelitian ini dilaksanakan di Lubuk Basung Kabupaten Agam dengan pertimbangan sebagai berikut: 1) Lubuk Basung memiliki lahan kering yang dimanfaatkan untuk tanaman jagung. 2) Lokasi terpilih mempunyai potensi untuk tanaman jagung, hasil penelitian didapatkan untuk kondisi fisika dan kimia tanah yang di ambil pada tiga satuan lahan yang berbeda mendapatkan hasil sesuai untuk ditamamkan jagung dan tingkat kesesuaian lahan untuk tanaman jagung pada satuan lahan Nagari garagahan dengan kriteria baik, dan satuan lahan nagari Kampung tangah dengan kriteria Sedang dan pada satuan lahan Nagari lubuk Basung dengan Kriteria Baik. Dan untuk Peta Model kesesuaian lahan Untuk tanaman jagung pada tiga satuan lahan tersebut di sesuaikan pada tingkatan dan kriteria yang didapatkan yaitu Nagari garagahan dengan kriteria baik, dan satuan lahan nagari Kampung tangah dengan kriteria Sedang dan pada satuan lahan Nagari lubuk Basung dengan Kriteria Baik.
\end{abstract}

Kata-kata kunci : Karakteristik lahan, Penggunaan lahan, Tingkat kesesuaian lahan dan Peta Model Kesesuaian lahan.

\begin{abstract}
Land is part of the landscape that includes the understanding of the physical environment (climate, topography, hydrology, even the state of natural vegetation) all of which will potentially affect land use. Malingono (Muryono, 2005) Land evaluation is an approach or a way of assessing the potential of land resources The results of the land evaluation will provide information and / or model of land use directives required. The objectives of this study are: Analysis of land suitability for maize in Kecamatan Lubuk Basung Agam Regency To answer these objectives, the things that are done are: 1) Analyzing the condition of land suitability in corn plants in Kecamatan Lubuk Basung Agam District. 2) Evaluating the level of land suitability in corn crops in Kecamatan Lubuk Basung Agam District 3) Making Map Model Land suitability for corn plant using Spatial analysis method in Kecamatan Lubuk Basung Agam Regency. This research was conducted in Lubuk Basung Agam Regency with the following considerations: 1) Lubuk Basung has dry land which is used for corn plant. 2) Selected sites have potential for maize crops, the results obtained for physical and chemical conditions of the soil taken in three different land units obtain suitable yields for maize and land suitability for maize on Nagari garagahan with good criteria, and land unit nagari Kampong tangah with criteria Medium and on land units Nagari Lubuk Basung with Good Criteria. And for the Land suitability model Map For the corn crops in the three units of land are adjusted to the level and criteria obtained are Nagari garagahan with good criteria, and the land area nagari Kampong tangah with criteria Medium and on landunits Nagari Lubuk Basung with Good Criteria.
\end{abstract}

Keywords: Land characteristics, Land use, Land suitability and Land suitability Model Map. 


\section{PENDAHULUAN}

Lahan adalah bagian dari bentang alam (landscape) yang mencakup pengertian lingkungan fisik (iklim, topografi, hidrologi, bahkan keadaan vegetasi alami) yang semuanya secara potensial akan berpengaruh terhadap penggunaan lahan. Malingreau, (Muryono (2008) mengemukakan bahwa Lahan merupakan suatu daerah di permukaan bumi yang ciri-cirinya mencakup semua pengenal yang bersifat cukup mantap dan dapat diduga berdasarkan daur dari biosfer, tanah, air, populasi manusia pada masa lampau dan masa kini sepanjang berpengaruh atas penggunaan lahan pada masa kini dan masa yang akan datang. Lahan memiliki sifat atau karakteristik yang spesifik. Evaluasi kesesuaian lahan sangat diperlukan untuk perencanakan penggunaan lahan yang produktif dan lestari. Penggunaan teknologi berbasis computer untuk mendukung perencanaan tersebut semakin diperlukan untuk menganalisis, memanipulasi dan menyajikan informasi dalam bentuk tabel dan keruangan. Salah satu teknologi tersebut adalah Sistem Informasi Geografi (SIG) yang memiliki kemampuan membuat model yang memberikan gambaran, penjelasan dan perkiraan dari suatu kondisi faktual. Oleh karena itu, penelitian ini dilakukan untuk mendapatkan model, informasi dan gambaran keruangan tentang komoditas yang cocok di Kecamatan Lubuk Basung Kabupaten Agam secara cepat dan akurat.

Di kecamatan lubuk basung Kabupaten agam sebagian besar lahann keringnya di pergunakan oleh masyarakat untuk bertanam jagung dan masyarakat mengantungkan perekonomiannya pada hasil produksi jagung tersebut, tanpa memperhatikan kesesuaian lahan nya.

Berdasarkan latar belakang dan masalah di atas maka penelitian ini bertujuan untuk: Mengetahui kondisi kesesuaian lahan (temperature, curah hujan, drainase, tektur tanah, kedalaman efektif perakaran, KTK liat, $\mathrm{pH}$ tanah, c organic tanah, kemiringan, ketinggian dan erosi) untuk tanaman jagung menggunakan metode analisis spasial di Kecamatan Lubuk Basung Kabupaten Agam,Mengevaluasi tingkat kesesuain lahan dan Membuat Peta Model Kesesuai lahan untuk tanaman jagung menggunakan metode analisis spasial di Kecamatan Lubuk Basung Kabupaten Agam.

\subsection{LANDASAN TEORI}

\subsubsection{Penggunaan Lahan}

Penggunaan lahan merupakanhasil akhir dari setiap bentuk campur tangan kegiatan manusia terhadap lahan di permukaan bumi yang bersifat dinamis dan berfungsi untuk memenuhi kebutuhan hidup baik material maupun spiritual Arsyad, (Suarna 2010).
Perubahan pengunaan lahan adalah bertambahnya suatu penggunaan lahan dari suatu sisi penggunaan ke penggunaan yang lainnya diikuti dengan berkurangnya tipe penggunaan lahan yang lain dari suatu waktu ke waktu berikutnya, atau berubahnya fungsi suatu lahan pada kurun waktu yang berbeda. (Wahyunto,dkk 2010, (Suryani 2013).

\subsubsection{Evaluasi kesesuaian lahan}

Kesesuain lahan actual adalah kesesusian lahan berdasarkan data sifat biofisik tanah atau sumber daya lahan sebelum lahan tersebut diberikan masukan-masukan yang diperlukan untuk mengatasi kendala. Data biofisiktersebut berupa karakteristik tanah dan iklim yang berhubungan dengan persyaratan tumbuh tanaman yang dievaluasi. Kesesuaian lahan potesial menggambarkan kesesuaian lahan yang akan dicapai apabila dilakukan usaha-usaha perbaikan lahan yang dievaluasi dapat berupa hutan konversi, lahan terlantar atau tidak produktif, atau lahan pertanian yang produktivitasnya kurang memuaskan tetapi masih memungkinkan untuk dapat ditingkatkan bila komoditasnya diganti dengan tanaman yang lebih sesuai (Ritung,dkk,2007

\subsubsection{Topografi}

Topografiyangdipertimbangandalamevalu asi lahan adalah bentuk wilayah (relief) atau lerengdan ketinggian tempat diatas permukaan laut. Relief erat hubungannya dengan aktor ketinggian tempat di atas permukaan laut berkaitan dengan persyaratan tumbu tanaman yang berhubungan dengan temperature udara dan radiasi matahari.

\subsubsection{Suhu udara}

Tanaman kina dan kopi, misalnya, menyukai dataran tinggi atau suhu rendah, sedangkan karet, kelapa sawit dan kelapa sesuai untuk dataran rendah.Pada daerah yang data suhu udaranya tidak tersedia, suhu udara diperkirakan berdasarkan tinggian tempat dari permukaan laut. Semangkin tinggi tempat, semangkin rendah suhu udara rata-ratanya dan hudubungan ini dapat dihitung dengan mengunakan rumus Braak (1928):6,3 ${ }^{\circ} \mathrm{C}(0,01 \mathrm{x}$ elevasi dalam meter $\left.\mathrm{x} 0,6^{\circ} \mathrm{C}\right)$ Suhu rata-rata di tepi pantai berkisar antara 25 $27^{\circ} \mathrm{C}$

\subsubsection{Tekstur tanah}

Tekstur tanah menunjukkan komposisi partikel penyusun tanah (separat) yang dinyatakan sebagai perbandingan proporsi $(\%)$ relatif antara fraksi pasir (sand) berdiameter 2,00-0,20 $\mathrm{mm}$ atau 2000-200um, debu (silt) berdiameter 0,20-0,002 $\mathrm{mm}$ atau 200- 
2um) dan liat (clay) $(<2$ um). Pertikel berukuran diatas $2 \mathrm{~mm} 34$ seperti kerikil dan bebatuan kecil tidak tergolong sebagai fraksi tanah, tetapi harus diperhitungkan dalam evaluasi tekstur tanah (Hanafiah,2012)

\subsubsection{Curah hujan}

Data curah hujan diperoleh dari hasil pengukuran stasiun penakaran hujan yang ditempatkan pada lokasi yang dianggap dapat mewakili suatu wilayah tertentu.Pengukuran curah hujan dapat dilakukan secara manual atau otomatis.Secara manual biasannya dicatat besarnya jumlah curah hujan yang terjadi selama 1 (satu) hari, yang kemudian dijumlahkan menjadi bulanan dan seterusnya tahunan.Sedangkan secara otomatis menggunakan alat-alat khusus yang dapat mencatat kejadian hujan setiap periode, misalnya setiap menit, setiap jam, dan seterusnya.

Berdasarkan criteria tersebut Oldeman 1975, Rutung 2007), mempunyai agroklimat kedalam 5 kelas (A,B,C,D danE).Sedangkan cmidt $\&$ Ferguson (1951) Data curah hujan diperoleh dari hasil pengukuran stasiun penakaran hujan yang ditempatkan pada lokasi penelitianmembuat klasifikasi iklim berdasrkan curah hujan yang berbeda, yakni bulan basah $(>100 \mathrm{~mm})$ dan bulan kering $(<60 \mathrm{~mm})$. Kriteria terakhir yang lebih bersifat umum untuk pertanian biasanya digunakan untuk penilaian tanaman tahunan.

Faktor tanah dalam evaluasi kesesuaian lahan ditentukan oleh beberapa sifat atau karakteristik tanah di antara drainase tanah, tekstur, kedalaman tanah dan retensi hara $(\mathrm{pH}, \mathrm{KTK})$, serta beberapa sifat lainnya diantaranya alkalinitas, bahaya erosi, dan bahaya banjir/genangan.

\subsubsection{Drainase tanah}

Drainase tanah menunjukkan kecepatan meresapnya air dari tanah atau keadaantanah yang menunjukkan lamanya dan seringnya januh air.Kelas drainase tanah table 2.4. kelas drainase yang sesuai untuk sebagian besar tanaman, terutama tanaman tahunan atau perkebunan berada pada kelas 3 dan 4. Dranase tanah kelas 1 dan 2 serta kelas 5,6 dan 7 kurang sesuai untuk tanaman tahunan karena kelas 1 dan 2 sangat redah meloloskan air. Sedangkan kelas 5, 6 dan 7 sering jenuh air dan kekuranganoksigen

\subsubsection{Tekstur tanah}

Tekstur tanah menunjukkan komposisi partikel penyusun tanah (separat) yang dinyatakan sebagai perbandingan proporsi (\%) relatif antara fraksi pasir (sand) berdiameter 2,00-0,20 mm atau 2000-200um, debu (silt) berdiameter 0,20-0,002 $\mathrm{mm}$ atau 200-2um) dan liat (clay) $(<2$ um). Pertikel berukuran diatas $2 \mathrm{~mm} 34$ seperti kerikil dan bebatuan kecil tidak tergolong sebagai fraksi tanah, tetapi harus diperhitungkan dalam evaluasi tekstur tanah (Hanafiah,2012)

\subsubsection{Kimia tanah/reaksi Tanah (pH)}

Keasaman tanah merupakan salah satu sifat yang paling penting. sebab $\mathrm{pH}$ sangat mempengaruhi ketersediaan unsur hara bagi tanaman. $\mathrm{pH}$ netral yaitu 5,5-6,5 maka unsur yang tersedia dalam jumlah yang cukup banyak, bila kurang dari 5,5 maka ketersedian unsur hara menurun dengan cepat, penentuan $\mathrm{pH}$ tanah secara teliti dapat dilakukan di laboratorium

\subsubsection{Sistem Informasi Geografi (SIG) untuk Analisis Model Spasial}

1.1.11.

Secara umum, terdapat dua jenis fungsi analisis di dalam SIG yaitu fungsi analisis spasial dan fungsi analisis atribut, yang termasuk ke dalam fungsi analisis spasial diantaranya adalah overlay dan buffering.

Overlay adalah salah satu dari fungsi analisis spasial yang menghasilkan data spasial baru dari minimal dua data spasial yang menjadi masukannya. Sebagai contoh, bila untuk menghasilkan wilayah-wilayah yang sesuai untuk budidaya tanaman tertentu (misalnya padi) diperlukan data ketinggian permukaan bumi, kadar air tanah, dan jenis tanah, maka fungsi analisis spasial overlay akan dikenakan terhadap ketiga data spasial (dan atribut) tersebut.

Buffering adalah salah satu dari fungsi analisis spasial yang menghasilkan data spasial baru yang berbentuk poligon atau zone dengan jarak tertentu dari data spasial yang menjadi masukannya. Data spasial titik akan menghasilkan data spasial baru yang berupa lingkaran-lingkaran yang mengelilingi titik-titik pusatnya. Untuk data spasial garis akan menghasilkan poligon yang melingkupi garis-garis. Demikian pula untuk data spasial poligon, akan menghasilkan data spasial baru yang berupa poligon-poligon yang lebih besar dan konsentris.(Prahasta, 2002: 74)

\section{PEMBAHASAN}

2.1. Kondisi fisika tanah dan kimia tanah (pH) tanah untuk tanaman jagung di kecamatan lubuk Basung Kabupaten Agam

Berdasarkan hasil penelitian dengan cara pengukuran lapangan dan analisa laboratoriumterhadap tujuh satuan lahan pada 3 satuan lahan yang berbeda, bahwa unsur tanah sangat menentukan tingkat seseuaina lahan untuk tanaman jagung dilihat dari segi kondisi fisika tanah dan kimian tanah $(\mathrm{pH})$ tanah dan unsur kimiringan 
lerang merupakan faktor yang dapat di pergunakan untuk mengukur tingkat sesuaian lahan untuk tananaman jagung

Adapun kondisi fisika lahan yang diukur tersebut adalah tekstur, stuktur, kedalaman efektif tanah, Drainase, kemiringan lereng, konsisten tanah dan sifat kimia tanah dan keasaman tanah $(\mathrm{pH})$.Berdasarkan hasil analisi data diatas, setiap kondisi fisika tanah dan kimia tanah yaitu keasaman tanah $(\mathrm{pH})$ menunjukan sifat-sifat yang dapat menjadi unsur untuk menganalisis tingkat keseusuaian lahan untuk tanaman.

Satu didapat kondisi fisika dan kimia tanah pada satuan lahan nagari Garagahan. jenis teksur tanah pasir berlempung, stuktur tanah gumpaldan lempung, kedalaman Afektif tanah $30 \mathrm{~cm}$, keadaan Drainasenya sangat baik, kemiringan lereng $10 \%$, konsisten tanah Gembur dan sifat kimia tanah yaitu keasaman tanah $(\mathrm{pH})$ agak jelek.

Dua di dapat kondisi fisika dan kimia tanah pada satuan lahan Nagari Kampung Tangah ini mempunyai. jenis tekstur tanah Lempung berpasir,stuktur tanah butir, kedalaman efektif tanah $16 \mathrm{~cm}$ keadaan Drainase jelek kemiringan lereng $8 \%$, konsisten tanah agak teguh dan sifat kimia tanah yaitu keasaman tanah $(\mathrm{pH})$ baik.

Tiga di dapat kondisi fisika dan kimai tanahpada satuan lahan nagari Lubuk Basung ini mempunyai. jenis teksur tanah pasir, stuktur tanah remah, kedalaman efektif tanah $25 \mathrm{~cm}$ keadaan Drainase baik, kemiringan lereng 20\%, konsisten tanah gembur dan sifat kimia tanah yaitu keasaman tanah $(\mathrm{pH})$ agak jelek.

\subsection{Tingkat kesesuain lahan untuk tanaman jagung di kecamatan lubuk Basung Kabupaten Agam}

Berdasarkan hasil penelitian tingkat kesesuain lahan untuk tanaman jagung di kecamatan lubuk basung kabupaten agam yang dilakukan pada tiga satuan lahan yang berbeda. berdasarkan atas Hammer ( 1981) dan Seta (1989) dengan sistem ceklist berdasarkan kriteria faktor - faktor penentu untuk analisis tingkat kesesuaian lahan un tuk tanman jagung yang dikemukan oleh Dibyosaputro ( 1999) dalam Hermon ( 2012 ) di dapatkankelas dan Tingkat kesesuaian lahan untuk satuan lahan nagari Garagahan dengan harkat 28 dengan kriteria baik dan kelas III, dan pada satuan lahan Kampung tangah dengan harkat 18 dan kriteria sedang dan kelas II, dan pada satuan lahan lubuk Basung dengan harkat 20 dan kriteria baik dan kelas III. Untuk lebih jelasnya dapat dilihat pada tabel berikut:
Tabel:Tingkat Kesesuain lahan untuk tanaman jagung di kecamatan lubuk basungkabupaten Agam

\begin{tabular}{|l|l|l|l|}
\hline No & Satuan lahan & $\begin{array}{c}\text { Tingkat } \\
\text { kesesuaian } \\
\text { lahan dengan } \\
\text { harkat }\end{array}$ & Kelas \\
\hline 1 & Geragahan & 28 (Baik) & III \\
\hline 2 & $\begin{array}{l}\text { Kampuang } \\
\text { Tangah }\end{array}$ & 18 (Sedang) & II \\
\hline 3 & $\begin{array}{l}\text { Lubuk } \\
\text { Basung }\end{array}$ & 20 (Baik) & III \\
\hline
\end{tabular}

2.3. Model Kesesuai lahan Untuk Tanaman Jagung di kecamatan lubuk Basung Kabupaten Agam.

Peta Model Kesesuai lahan Untuk Tanaman Jagung di kecamatan lubuk Basung Kabupaten Agam di buat berdasarkan pada kriteria yang telah di dapat berdasarkan tingkatan kesesuai lahan yang telah di dapat pada tiga satuan lahan yang diteliti yaitu pada satuan lahan Nagari Garagahan Kriterian Baik, Nagari Kampung Tangah Kriteria Sedang dan Nagari Lubuk Basung Kriteria Baik, Peta Model Keseuain lahan ini di buat dengan menggunakan Sistem Informasi Geografi (SIG) untuk Analisis Model Spasial

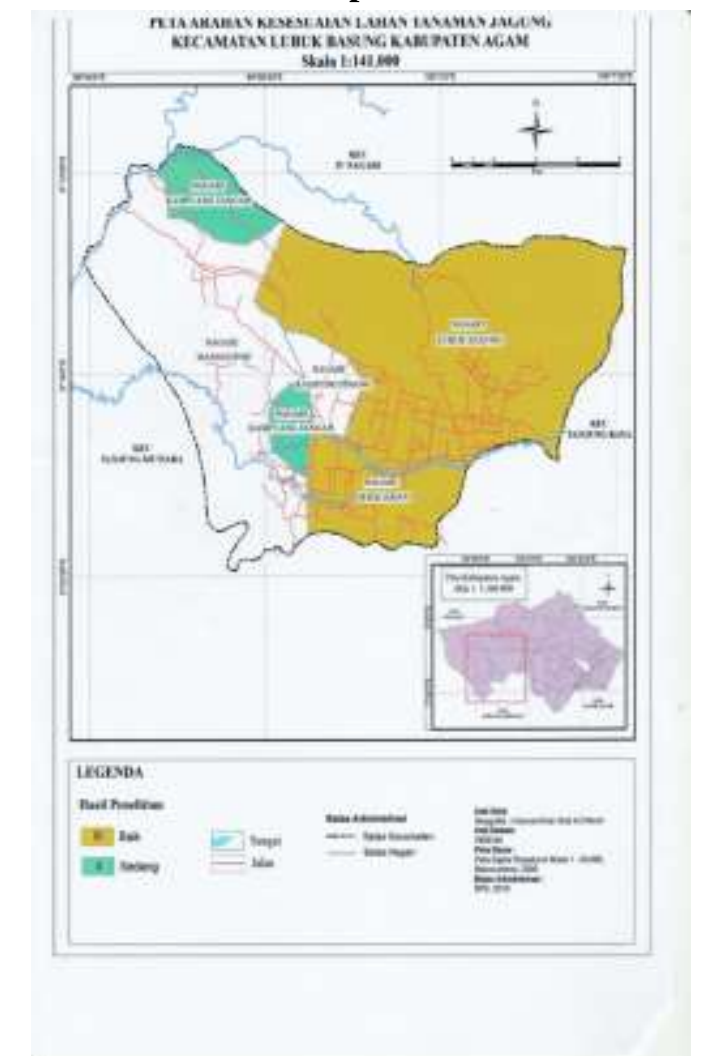

Peta model kesesuai lahan untuk tanaman jagung pada daerah penelitian 


\section{KESIMPULAN DAN SARAN}

\subsection{Kesimpulan}

Kesimpulan yang dapat diperoleh pada penelitian saat ini adalah penelitian sudah dilakukan pada tahap pralapangan, tahap lapangan yaitu pengukuran dilapangan dan Analisis uji laboratoriaum. Terdapat Terdapat hasil penelitian didapatkan untuk kondisi fisika dan kimia tanah yang di ambil pada tiga satuan lahan yang berbeda mendapatkan hasil sesuai untuk ditamamkan jagung dan tingkat kesesuaian lahan untuk tanaman jagung pada satuan lahan Nagari garagahan dengan kriteria baik, dan satuan lahan nagari Kampung tangah dengan kriteria Sedang dan pada satuan lahan Nagari lubuk Basung dengan Kriteria Baik. Dan Peta Model kesesuaian lahan untuk tanaman jagung di buat berdasarkan Kriteria yang di dapat pada tiga satuan lahan tersebut yaitu Nagari garagahan dengan kriteria Baik, disatuan lahan nagari Kampung tangah dengan kriteria Sedang dan pada satuan lahan Nagari lubuk Basung dengan Kriteria Baik,

\section{DAFTAR PUSTAKA}

Arsyad, S.( 2006). Konservasi Tanah dan Air.IPB Press.Bogor.

Djaenuddin. D, Marwan. H, H. Subagyo Anny Mulyani, dan N. Suharta. (2000). Kriteria Kesesuaian Lahan UntukKomoditas Pertanian Versi 3.0.Pusat Penelitian Tanah dan Agroklimat. Bogor.

Siswanto, 2006, Evaluasi Sumber Daya lahan, UPN Pres, Surabaya.

Hardjowigeno,Sarwono.2003. Klasifikasi Tanah dan Pedogenesis,Akademika Pressindo.Jakarta.

Harniati, Revi Marsusi, Djamaluddin Sahari, dan Purnawati. (2000).

TeknologBudidayaTanaman Jagung Di
LahanKering.Lokasi PengkajianTeknologi Pertanian Pontianak.Badan Penelitian dan Pengembangan Pertanian.Departemen Pertanian Pontianak.

Haryanto, E. 2001.Perubahan Penggunaan Lahan Dan Implikasinya Terhadap Koefesien Air Aliran DAS Citarum Hulu Jawa Barat.Penelitian UniversitasPadjadjaran.

Hermon,D dan Khairani.2009. Geografi Tanah, Yayasan Jihadul khair Center. Padang.

Hidayat.A, Hikmatullah, dan P. Santoso.(2000). Potensi dan Pengelolaan Lahan Kering Dataran Rendah dalam Sumber Daya Lahan Indonesia dan Pengelolaannya.Pusat Penelitian Tanah dan Agroklimat. Bogor.

Kartasapoetra ,Gunarsi Ance.2012.Klimatologi Pengaruh Iklim Terhadap Tanah dan Tanaman.Bumi Aksara.Jakarta

Maleong Lexy J ( 2007 )Metode Penelitian Kualitatif, Remaja Rosdakarya,Bandung.

Muryono. 2008. Arahan Fungsi Pemanfaatan Lahan Daerah Aliran Sungai Samin Kabupaten Karanganyar Dan Kabupaten Sukoharjo Tahun 2007.Skripsi.Surakarta : Universitas Sebelas Maret

Prahasta, E. 2005. Sistem Informasi Geografi Konsep-Konsep Dasar.Informatika. Bandung.

Suryani, 2014, Tingkat Degradasi Fisik Lahan Daerah Aliran Sungai (DAS) Batang Kuranji Kota Padang, Tesis UNP

Ritung,dkk.2007, Panduan Evaluasi kesesuaian lahan dangan contoh Peta Arahan Penggunaan lahan Kabupaten Aceh Barat, Balai Penelitian Tanah dan Worid Agroforestry Center (ICRAF), Bogor, Indosesia. 